\title{
Anônimo, caiu na praia o Grupo do Castelo: uma resenha do livro Esporte, lazer e estilos de vida, de Marco Paulo Stigger
}

Ricardo de F. Lucena*

Instigante! É com essa palavra que devo iniciar a análise que faço do trabalho que o prof. Stigger nos apresenta. Um trabalho de fôlego, que não inibe em chamar ao diálogo autores de peso. Marco Stigger, ao longo do texto, mantém uma conversa profícua com vários autores na busca da compreensão de uma questão aparentemente simples - mas só aparentemente - acerca do esporte. A questão é a seguinte: o esporte é uma prática homogênea ou é uma atitude heterogênea? Ou, como coloca o autor em um dos subitens: "Esporte: homogeneidade ou heterogeneidade?"(p.16) Àqueles que se contentam com um primeiro olhar, podem pensar que a resposta é óbvia, e é aí que mora o perigo. Perigo que Stigger bem enxergou e que nos apresenta de forma bastante instigante. Ou seja, aconselha, estimula, persuade o leitor ao longo de todo o texto.

O autor faz sua primeira advertência aos incrédulos (ou aos crédulos em demasia) já no início do texto quando, marcando a crescente importância do esporte no mundo contemporâneo, aponta que parte das teorizações identifica o fenômeno esportivo de uma forma ingênua e descontextualizada, atribuindo-lhe apenas virtudes. Numa outra perspectiva, aponta o autor, que interpretam o esporte " apenas como resultado do processo de industrialização da sociedade, da dominação do capital e da ideologia dominante" (p.03).

Assim, objetiva para além de "reconhecer o esporte como um fenômeno cultural que traz consigo um universo de significações hegemonicamente colocadas", compreendê-lo como uma prática social inserida no âmbito do lazer das pessoas comuns, vendo-o como um elemento constitutivo de diferentes estilos de vida (p.33). Isso fica evidente nas falas dos sujeitos e nas descrições dos grupos observados. Mas, o melhor é que o discurso de Stigger nos traz muito mais coisas acerca do problema que elege. O seu diálogo com Brohm, Elias, Dunning, Bouet, Guttman, Mandell, Bento e outros, ao longo do texto e em especial no primeiro

* Prof. Dr. do Departamento de Educação Física/ UFPE.

Movimento, Porto Alegre, v. 9, n. 2, p. 159-161, maio/agosto de 2003 
capítulo, mostra o quão diversas e distintas são as questões que o tema permite abordar.

O estudo etnográfico que o autor nos apresenta, como ele mesmo chama a atenção, não se resume a simples descrição de um fenômeno cultural restrito a grupos singulares. Sua riqueza está justamente na possibilidade que aponta para a criação de uma teia de relações que marcam a presença do homem(ou dos homens!) em tudo que é social. Isso parece evidente, mas, como dissemos anteriormente, é nas evidências que reside a expressão - ou o disfarce - de nossa miopia. Nem sempre a relação indivíduo e sociedade está presente em nossas análises. Ouso dizer até que, invariavelmente, essa questão é tratada como uma simples oposição. Ou seja, de um lado estão os indivíduos, e do outro, a sociedade, como se um existisse independentemente do outro. A análise de Stigger considera e trabalha com essa relação superando uma repartição primária. Nesse sentido, os grupos por ele analisados - o Grupo do Castelo, Caídos na Praia e Anônimos - não são uma simples reunião de indivíduos, um simples aglomerado de sujeitos que se misturam com uma idéia geral de sociedade nem um agrupamento de indivíduos que se percebem como partes isoladas de um todo difuso e complexo. Eles formam uma configuração, e as configurações de indivíduos são irredutíveis. Isso o autor apreende com muita propriedade na sua pesquisa empírica. Nesse aspecto, o texto me remete a uma passagem de um trabalho de Norbert Elias que bem esclarece a relação que venho tentando apresentar quando falo das configurações analisadas por Stigger:

...Dizer que os indivíduos existem em configurações significa que o ponto de partida de toda investigação sociológica é uma pluralidade de indivíduos, os quais, de um modo ou de outro, são interdependentes. Dizer que as configurações são irredutíveis significa que nem se pode explicá-las em termos que impliquem que elas têm algum tipo de existência independente dos indivíduos, nem em termos que impliquem que os indivíduos, de algum modo, existem independente delas (Elias, 2000, p. 184).

Foi isso que o autor fez com muita sabedoria. Juntamente com os indivíduos, analisou as configurações que eles formam. E o fez com critério. Cada grupo vem se inserir num contexto onde a ação no esporte faz ressaltar a interdependência entre indivíduos que, em maior ou menor grau, se fazem presentes em cada configuração analisada.

Não cabe aqui entrar em detalhes sobre os caminhos da análise em cada grupo em particular. Estes podem ser buscados ao longo e à medida que vamos nos envolvendo com a leitura. Mas cabe

Movimento Porto Alegre, v. 09, n. 2, p. 159-161, maio/agosto de 2003 
anotar a heterogeneidade que o autor ressalta quanto ao desenvolvimento de maneiras específicas de prática do esporte. Essas maneiras não estão, de forma alguma, desconectadas de "outras vidas" vividas coletivamente. Nesse sentido, destaca que, "nos grupos investigados na cidade do Porto, a prática esportiva acaba por ampliar os horizontes sociais dos indivíduos, inserindo-os noutras redes de sociabilidade, queirão integrá-los noutros contextos da sociedade em que vivem" (p.223).

Por fim, o que fica evidente é a trama reticular que nos mantém presos a uma tensão criada por dependências mútuas que marcam a presença do indivíduo no grupo, particularmente nos grupos cuja motivação está ligada às práticas esportivas. $\mathrm{Ou}$, como diria Stigger:

...As atividades esportivas oferecem referências para que os indivíduos organizem a sua vida social, sendo desenvolvido, nesse convívio, um processo de socialização dos participantes dos grupos, os quais - ao viverem coletivamente - passam a compartilhar maneiras de estar no mundo, que são expressas tanto dentro quanto fora do campo de jogo (p. 245).

Portanto, a obra Esporte, lazer e estilos de vida, que nos dá a conhecer os grupos do Castelo, os Caídos na Praia e os Anônimos, da cidade do Porto, em Portugal, é um estudo etnográfico da melhor lavra, que, a meu ver, nos deixa uma confirmação e um desafio: primeiramente, é que a área se ressentia de análises dessa natureza, e, segundo, que o objetivo proposto foi plenamente alcançado, e novas "parcerias" serão bem-vindas para animar essa seara.

\section{Referências}

ELIAS, Norbert \& SCOTSON, John L. Os estabelecidos e os outsiders. Rio de Janeiro: Jorge Zahar Ed., 2000.

STIGGER, Marco Paulo. Esporte, lazer e estilos de vida: um estudo etnográfico. Campinas, SP: Autores Associados, 2002. 